\title{
UPAYA MENINGKATKAN EFISIENSI BIAYA PEMERIKASAAN DENGAN MENGGUNAKAN STANDAR BIAYA KHUSUS YANG BERBASIS KINERJA PADA INSPEKTORAT KOTA PALOPO
}

\author{
ANDI WAHIDIN, GOSO, MUSTAFA MUHANI
}

\begin{abstract}
ABSTRAK
Kinerja adalah hasil pekerjaan seseorang dalam suatu organisasi, hasil pekerjaan tersebut dapat menyangkut kualitas, kuantitas, dan ketepatan waktu. Variabel dalam penelitian ini terdiri atas dua yaitu : 1)Upaya meningkatkan efisiensi pemeriksaan (X) serta 2)Standar Biaya Khusus berbasis Kinerja (Y). Penelitian ini bertujuan untuk mengetahui kesesuaian relevansi pengalokasian biaya pemeriksaan melalui Standar Biaya Khusus yang ditetapkan melalui Peraturan Walikota No. 18 tahun 2010 dengan (Output) berupa laporan hasil pemeriksaan suatu kegiatan yang direncanakan kinerja aparat pengawas internal pada Inspektorat Kota palopo..

Metode Penelitian yang digunakan yaitu Metode observasi dan metode wwancara

Berdasarkan hasil penelitian diketahui hasil hasil capaian kinerja pada inspektor Kota palopo T.A. 2010 yang dihitung berdasarkan indikator output dengan menggunakan tolak ukur volume fisik dan keuangan dari seluruh pelaksanaan program dan kegiatan menunjukkan rata-rata nilai capaian kinerja fisik secara total sekitar 459,30\% atau dikategorikan sangat baik. Sedangkan rata-rata capaian kinerja keuangan 76,99\% atau dikategorikan baik. Sedangkan pada T.A 2010 anggaran pemeriksaan Inspektorat Kota Palopo hanya terealisasi sebesar 0,20\% dan selama tiga(tiga) tahun anggaran terahkhir proporsi anggaran biaya pemeriksaan Inspektorat Kota Palopo belum pernah mencapai minimal satu (satu) persen dari total APBD kota Palopo
\end{abstract}

Kesimpulannya bahwa capaian kinedrja inspektorat Kota palopo pada T.A 2010 berdasarkan tugas pokok dan fungsi sebesar 459,30\% atau dikategorikan sangat baik untuk kinerja fisik, sedangkanuntuk kinerja keuangan sebesar 76,99\% atau dikategorikan baik. Biaya pemeriksaan Inspektorat Kota Palopo diterapkan melalui Standar Biaya Khusus. Dan Tingkat kesejahteraan dan motivasi kerja aparat pengawas intrn pemerintah (APIP) dan tenaga fungsional (auditor) belum terpenuhi.

Kata Kunci: Efisiensi Biaya Pemeriksaan, Standar Biaya Khusus, Berbasis Kinerja. 


\section{Pendahuluan}

\section{Latar Belakang}

Dalam zaman refornasi saat ini pemerintah berupaya mewujudkan tata kelola pemerintahan yang baik (good govermance). Keseriusan ini dibuktikan dengan usaha-usaha untuk meningkatkan transparansi akuntabilitas melalui pengelolaan keuangan baik ditingkat Pemerintah Pusat maupun di tingkat Pemerintah Daerah mencakup fungsi pengawasan dalam penyelenggaraaan Pemerintahan daerah yang dilaksanakan oleh Pemeriksaan Eksternal dan Aparat Pengawasan Intern Penmerintah (APIP).

Inspektorat kota palopo merupakan salah satu unit APIP yang berada dalam lingkup pengawasan internal yang mempunyai tugas pokok melakukan pembinaan dan pengawasan serta sebagai (early warning) terhadap adannya penyimpangan terhadap penyelenggaraan pemerintah daerah kota palopo dalam rangka menciptakan akuntabilitas keuangan mendukung program pemberantasan korupsi.

Inspektorat kota palopo merupakan bagian pemerintahan umum yang menyelenggarakan fungsi pembinaan dan pengawasan internal bagi pemerintah daerah kota palopo perlu didukung input yang jelas baik itu dari segi penganggaran maupun penyediaan Sumber daya manusia (SDM) dalam menjalankan tugas pokok dan fungsinya guna menghasilkan output berupa laporan hasil pemeriksaan yang kredibilitas dan bermanfaat bagi setiap penggunanya.

Pada tahun 2010 pencapaian kinerja inspektorat kota palopo melalui laporan akuntabilitas kinerja pemerintah (LAKIP) berdasarkan tugas pokok dan fungsi mencapai 76,99\% untuk kinerja keuangan (dikategorikan baik), sedangkan untiuk kinerja fisik menca;pai 459,30\% (dikategorikan paling baik) dari target pemeriksaan dan kegiatan operasional lainnya yang ditetapkan dalam APBN tahun 2010. Hal ini menggambarkan, walaupun sangat terbatasnya penyediaan dana operasional bagi inspektorat oleh pemkotpalopo yang tidak tersedianya anggaran $100 \%$.

Pada tahu 2011, pemerintah kota palopo telah memberikan anggaran belanja pada inspektorat kota palopo sebesar Rp. 3.445.753.990 dari total APBD kota palopo Rp. 472.300.193.670. hal ini masih jauh dari apa yang digambarkan oleh menteri dalam negeri melalui keputusan Mendagri No.700-462 tahun 2007. Bahwa untuk anggaran pengawasan pada penyelenggaraan pemerintah daerah dibutuhkan minimal 1 (satu) persen dari anggaran pendapatan dan belanja daerah.

Kurangnya perhatian pemerintah kota palopo menyebabkan inspektorat kota palopo yang membidangi fungsi penyelenggaraan pemerintahan belum optimal melaksanakan pembinaan dan pengawasan terhadap APBD karena keterbatasan Anggaran Pemeriksaan. Masalah penelitian ini yaitu Apakah standar biaya khusus melalui peraturan walikota palopo No 18 tahun 2010 mengacu kepada kinerja dalam meningkatkan efisiensi pemeriksaan pada inspektorat kota palopo?. Tujuan dari penelitian ini adalah untuk mengetahui kesesuaian relevansi pengelolaan biaya pemeriksaan melalui standar biaya khusus yang ditetapkan melalui peraturan 
walikota No. 18 tahun 2010 dengan keluaran (output) berupa laporan hasil pemeriksaan suatu kegiatan yang direncanakan kinerja aparat pengawas internal pada inspektorat palopo serta dapat diperoleh pembiayaan pemeriksaan kegiatan secara wajar dan efisien.

\section{Metode Penelitian}

Tempat dan Waktu Penelitian

Penelitian ini dilakukan pada Pemerintah Daerah Kota Palopo melalui satuan kerja perangkat daerah (SKPD) yaitu inspektorat Kota Palopo tahun anggaran 2010

Jenis dan Sumber Data

1. Data Primer

2. Data Skunder

3. Studi Kepustakaan

Populasi dan Sampel

Populasi yang ada dalam penelitian ini

Metode Pengumpulan Data

Metode Pengumpulan data yang digunakan adalah: (a) Observasi; Data dikumpulkan melalui pengamatan langsung guna mengetahui standar atau aturan yang ditetapkan dalam melakukan perhitungan biaya pemeriksaan sesuai standar biaya khusus yang diterapkan dalam peraturan walikota palopo, (b) wawancara; Teknik ini dilakukan untuk memperoleh keyakinan atas jawaban yang diperoleh dari pengumpulan data teknik lain serta memperoleh tambahan informasi dari responden

Metode Analisis Data

Penulisan Skripsi ini menggunakan metode analisis deskriptif yaitu dengan menggambarkan bagaimana pelaksanaan penganggaran biaya pemereiksaan dengan menggunakan kinerja berdasarkan data dari studi yang dilakukan.

\section{Penelitian Dan Pembahasan}

\section{Hasil Penelitian}

Dalam Upaya meningkatkan efisiensi biaya pemeriksaan dengan menggunbakan standar biaya khusus yang berbasis kinerja pada Inspektorat Kota Palopo. Penelitian Ini menggunakan analisis deskriktif yaitu dengan menggambarkan bagaimana pelaksanaan penganggaran biaya pemeriksaan dengan menggunakan kinerja berdasarkan data dari studi yang dilakukan melalui dokumentasi, wawancara, dan pengamatan langsung. 


\section{Pembahasan Hasil Penelitian}

\section{Perbandingan Pencapaian Kinerja Fisik dan Kinerja Keuangan pada Inspektorat Kota Palopo}

Capaian kerja keuangan dan fisik pada 2 (dua) program pokok di atas dapat digambarkan dalam bentuk tabel sebagai berikut:

Tabel. 1

Capaian Kinerja Keuangan dan Fisik T.A 2010

\begin{tabular}{|c|c|c|c|c|c|c|}
\hline \multirow{2}{*}{ No } & \multirow{2}{*}{ Program/Kegiatan } & \multicolumn{2}{|r|}{ Target } & \multicolumn{2}{|c|}{ Realisasi } & \multirow{2}{*}{ Ket } \\
\hline & & Fisik & Keuangan & Fisik & Keuangan & \\
\hline 1 & 2 & 3 & 4 & 5 & 6 & 7 \\
\hline 1. & $\begin{array}{l}\text { Program } \\
\text { Peningkatan } \\
\text { Sumber daya Alam }\end{array}$ & 8 & 69.000.00,- & 4 & $32.543 .000,-$ & $\begin{array}{l}22,22 \% \\
47,16 \%\end{array}$ \\
\hline 2. & $\begin{array}{l}\text { Program } \\
\text { peningkatan } \\
\text { Sistem pengawasan } \\
\text { Internal dan } \\
\text { pengendalian }\end{array}$ & 68 & $681.570 .000,-$ & 391 & $\begin{array}{c}545,230.000 \\
-\end{array}$ & $\begin{array}{l}575,00 \% \\
80,01 \%\end{array}$ \\
\hline & $\begin{array}{l}\text { Rata-rataa capaian } \\
\text { kinerja } \\
\text { Fisik }\end{array}$ & 43 & & 198 & & $459,30 \%$ \\
\hline & $\begin{array}{ll}\text { Rata-rata capaian } \\
\text { kinerja } & \\
\text { Keuangan } & \end{array}$ & & $375.235 .000,-$ & & $\begin{array}{c}288.886 .500, \\
-\end{array}$ & $76,99 \%$ \\
\hline
\end{tabular}

(Sumber: lankip Inspektorat Kota Palopo T.A 2010)

Gambaran diatas menunjukkan bahwa hasil capaian kinerja pada inspektor Kota palopo T.A. 2010 yang dihitung berdasarkan indikator output dengan menggunakan tolak ukur volume fisik dan keuangan dari seluruh pelaksanaan program dan kegiatan menunjukkan rata-rata nilai capaian kinerja fisik secara total sekitar 459,30\% atau dikategorikan sangat baik. Sedangkan rata-rata capaian kinerja keuangan 76,99\% atau dikategorikan baik.

Kedua program tersebut diatas, merupakan tugas pokok dan fungsi yang melekat pada unsur pembinaan dan pengawasan Pemerintahan daerah yang hanya berada pada Inspektorat Kota Palopo dan telah menjadi Program Kerja Pengawasan tahunantelah memenuhi kriteria untuk disusun dalam Standar Biaya Khusus ( SBK) melalui peraturan Walikota palopo Nomor 18 tahun 2010, namun satuan biaya pemeriksaan per hari pemeriksaan masih terlalu rendah bila dibandingkan dengan Proporsi APBD kota Palopo.

Adapun proporsi Anggaran Pendapatan dan Belanja daerah (APBD) Pemerintah Kota Palopo T.A 2010 terhadap total anggaran biaya pemeriksaan Inspektorat Kota Palopo T.A 2010 dapat digambarkan sebagai berikut:
a. APBD T.A 2010
$=$ Rp. $\quad 367.719 .471 .365,-$
b. Anggaran Pemeriksaan T.A 2010
$=\mathrm{Rp}$.
750.470 .000
c. Presentase
$=0,20 \%$ 
Tabel. 2

Presentase Penyediaan Biaya Pemeriksaan Terhadap APBD Kota Palopo dari T.A $2009-2011$

\begin{tabular}{|c|c|c|c|c|}
\hline No & $\begin{array}{c}\text { Tahun } \\
\text { Anggaran }\end{array}$ & \multicolumn{1}{|c|}{ APBD } & Biaya Pemeriksaan & Presaentase \\
\hline 1. & 2009 & Rp. 371.370.493.317,- & Rp. 1.132.390.038,- & $0,30 \%$ \\
2 & 2010 & Rp. 367.719.471.365,- & Rp. 740.470.000,- & $0,20 \%$ \\
3 & 2011 & Rp. 475.374.604.940,- & Rp. 1.004.730.000,- & $0,21 \%$ \\
\hline
\end{tabular}

(Sumber: APBD Kota Palopo T.A 2009 - 2010)

Tabel diatas menggambarkan bahwa pada T.A 2010 anggaran pemeriksaan Inspektorat Kota Palopo hanya terealisasi sebesar 0,20\% dan selama tiga(tiga) tahun anggaran terahkhir proporsi anggaran biaya pemeriksaan Inspektorat Kota Palopo belum pernah mencapai minimal satu (satu) persen dari total APBD kota Palopo.

\section{Penutup}

Kesimpulan penelitian ini adalah bahwa capaian kinedrja inspektorat Kota palopo pada T.A 2010 berdasarkan tugas pokok dan fungsi sebesar 459,30\% atau dikategorikan sangat baik untuk kinerja fisik, sedangkanuntuk kinerja keuangan sebesar 76,99\% atau dikategorikan baik. Biaya pemeriksaan Inspektorat Kota Palopo diterapkan melalui Standar Biaya Khusus. Dan Tingkat kesejahteraan dan motivasi kerja aparat pengawas intrn pemerintah (APIP) dan tenaga fungsional (auditor) belum terpenuhi. Adapun saran dari penelitian ini yaitu: (a) Dalam memenuhi pencapaian kinerja keuangan $100 \%$ pada inspektorat kota palopo diharapkan pmerintah daerah palopo memberikan skala prioritas pada penyediaan dana pemeriksaan khusunya program dan kegiatan yang menjadi tugas pokok dan fungsi pengawasan, (b) Idealnya pemerintah daerah kota palopo mampu mengalokasikan anggaran biaya pemeriksaan minimal satu (1) persen dari total APBD. (c) Motivasi kinerja davn prestasi aparat pengawas intern pemerintahan dan tenaga fungsional (auditor) dengan memberikan tunjanganb kelangkaan profesi dan beban kerja.

\section{Daftar Pustaka}

A.A Anwar Prabu Mangkunegara, (2005), Evaluasi Kinerja Sumber Daya Manusia

Agus Darma, (1991), Manajemen Prestasi

Badan Pengawasan Keuangan dan Pembangunan, (1996), standar Audit Aparat Pengawasan Fungsional Pemerintah (SA-APFP) 
Inspektorat Kota Palopo, (2008), Laporan Akuntabilitas Kinerja Instansi Pemerintahan Inspektorat Kota Palopo T.A 2009

Inspektorat Kota Palopo, (2009), Laporan Akuntabilitas Kinerja Instansi Pemerintahan Inspektorat Kota Palopo T.A 2010

Kementrian Dalam Negeri, (2007), Keputusan Mentri Dalam Negeri No. 700-462 tahun 2007 tentang kebijakan Pengawasan Penyelenggaraan Pemerintah daerah tahun 2008

Kementrian Keuangan, (2010), Peraturan Mentri Keuangan Nomor 100/Pmk.02/2010 Tentang Standar Biaya Tahun Anggaran 2011

Kementrian Dalam Negeri, (2010), Peraturan Mentri Dalam Negeri No. 15 tahun 2010 tentang Pedoman Pengawasan Penyelenggaraan Pemerintah daerah tahun 2011 